\title{
Degenerative joint disease in cattle and buffaloes in the Amazon region: a retrospective study ${ }^{1}$
}

\author{
José Diomedes Barbosa ${ }^{2 *}$, Danillo Henrique S. Lima ${ }^{2}$, Alessandra S. Belo-Reis ${ }^{2}$, \\ Cleyton P. Pinheiro ${ }^{2}$, Melina G.S. Sousa ${ }^{2}$, Jenevaldo B. Silva ${ }^{3}$, Felipe M. Salvarani ${ }^{2}$ \\ and Carlos Magno C. Oliveira ${ }^{2}$
}

\begin{abstract}
Barbosa J.D., Lima D.H.S., Belo-Reis A.S., Pinheiro C.P., Sousa M.G.S., Silva J.B., Salvarani F.M. \& Oliveira C.M.C. 2014. Degenerative joint disease in cattle and buffaloes in the Amazon region: a retrospective study. Pesquisa Veterinária Brasileira 34(9):845850. Instituto de Medicina Veterinária, Universidade Federal do Pará, Rodovia BR-316 Km 61, Bairro Saudade, Castanhal, PA 68740-970, Brazil. E-mail:diomedes@ufpa.br

A retrospective study of the epidemiological and clinic-pathological aspects of cattle and buffaloes with degenerative joint disease (DJD) was conducted in the state of Pará, Brazil. From 1999 to 2014, eleven cattle and 24 buffaloes were evaluated. All the treated animals with suspected DJD underwent a clinical examination of the musculoskeletal system. In seven cattle and eight buffaloes with clinical signs of the disease postmortem examination was performed. The common clinical signs observed in both species were chronic lameness, stiff gait, postural changes, audible crackles in the affected limb, prolonged recumbency, difficulty in getting up and progressive weight loss. The lesions observed at necropsy were: irregular articular surfaces, erosion of the articular cartilage and the underlying bone tissue, and proliferation of the periarticular bone tissue with formation of osteophytes. The most affected joints in cattle and buffaloes wereof the hind limb. In buffaloes, the main predisposing factor to the onset of DJD was phosphorus deficiency. In cattle, defects of the anatomical conformation of the hind limbs, chronic trauma due to the activities performed, such as semen collection, and advanced age possibly contributed to the emergence of the disease.
\end{abstract}

INDEX TERMS: Amazon region, cattle, buffaloes, lameness, joint diseases, osteoarthritis.

RESUMO.- [Doença articular degenerativa em bovinos e búfalos na Amazônia: estudo retrospectivo.] Foi realizado um estudo retrospectivo sobre os aspectos epidemiológicos e clínico-patológicos em bovinos e búfalos com doença articular degenerativa (DAD) no estado do Pará, Brasil. Durante os anos de 1999 a 2014 foram avaliados 11 bovinos e 24 bubalinos. Todos os animais atendidos com suspeita clínica de DAD foram submetidos a exame clínico do sistema locomotor. Foram necropsiados sete bovinos e oito bubalinos com sinais clínicos da enfermidade. Os sinais clínicos comuns ob-

\footnotetext{
${ }^{1}$ Received on July 4, 2014.

Accepted for publication on August 7, 2014.

${ }^{2}$ Instituto de Medicina Veterinária, Universidade Federal do Pará (UFPA), Rua Maximino Porpino da Silva 1000, Castanhal, PA 68740-080, Brazil. *Corresponding author: diomedes@ufpa.br

${ }^{3}$ Faculdade de Ciências Agrárias e Veterinárias, Universidade Estadual Paulista (Unesp), Via de acesso Prof. Paulo Donato Castellane s/n, Jaboticabal, SP 14884-900, Brazil.
}

servados em ambas as espécies foram claudicação crônica, andar rígido, alterações posturais, crepitações audíveis no membro acometido, decúbito prolongado, dificuldade para levantar, e emagrecimento progressivo. As lesões articulares evidenciadas na necropsia consistiram em irregularidade da superfície articular, presença de erosão na cartilagem articular e no tecido ósseo subjacente, proliferação de tecido ósseo periarticular com formação de osteófitos. Tanto nos bovinos como nos bubalinos as articulações mais acometidas foram as dos membros posteriores. Nos bubalinos, possivelmente o principal fator predisponente ao surgimento de DAD foi à deficiência de fósforo, ao contrário dos bovinos, nos quais os defeitos de conformação anatômica dos membros posteriores, traumas crônicos em virtude da atividade exercida, como a coleta de sêmen e a idade avançada, foram o que, possivelmente, contribuíram para surgimento da enfermidade.

TERMOS DE INDEXAÇÃO: Amazônia, búfalos, bovinos, claudicação, doença articular, osteoartrite. 


\section{INTRODUCTION}

Degenerative joint disease (DJD), also known as osteoarthritis, is characterized by a degradation of the articular cartilage leading to morphological changes in the joint. The consequences of cartilage degradation are inflammation of the synovial membrane and abnormal bone proliferation within the joint (Desrochers 2013). This disease is mainly characterized by primary degeneration of the articular cartilage and may affect one or several joints at the same time, affecting both young and adult animals (Weaver 1997).

DJD is highly prevalent in humans (Brooks 2002) and in animals, especially in dogs (Biasi et al. 2005) and horses (Frisbie et al. 2008, Baccarin et al. 2012). DJD is also commonly reported in cattle (Persson et al. 2007, Heinola et al. 2013), but to date, descriptions of DJD in buffaloes and mini cattle have not been found in the literature.

Articular lesions have been diagnosed in cattle since the beginning of veterinary medicine (Shupe 1961). A paleontological study reports the occurrence of depressions on the articular surface in archaeological collections of bones of cattle from England and Denmark (Thomas \& Johannsen 2011). The authors emphasize that such changes due to DJD are common but are poorly studied in sets of archaeological bones. Other authors stress the fact that DJD is more common than normally considered (Heinola et al. 2013). A radiographic study conducted with 50 male cattle raised in a feedlot in the state of Goiás indicated that the main lesions observed resulted from DJD (27.5\%), osteitis (19.6\%) and periostitis (15.7\%) (Lima 2009).

The etiology of DJD is not well defined. However, in most cases, the origin of lesions is considered multifactorial. Heredity, gender, growth rate, body weight, acute traumatic joint injury, joint instability caused by ruptured ligament or tendon, anatomical conformation defects, the natural aging process and nutritional deficiencies have been proposed as possible etiological factors (Radostits et al. 2002, Nichols \& Lardé 2014). Lesions usually begin with a process that involves loss of the regular and smooth articular cartilage surface and may extend to the reparative and/or osteophyte-formation processes (Takizawa et al. 2008).

Animals affected by DJD may have varying degrees of swelling and deformity of the joints (Carlton \& McGavin 1998), stiff gait, lameness that may occur in one or more limbs and pain on joint flexion. The animals usually have low body condition scores due to chronic pain, with consequent reduction in the production of milk and meat (Rebhun 2000, Nichols \& Lardé 2014). Crackles may be audible at circumduction of the affected limb, and the sick animals may remain in prolonged recumbency and may have difficulty to stand up and walk. The bony prominences of the joints may be more prominent than normal due to muscle disuse atrophy (Tryon \& Farrow 1999, Scott et al. 2000, Radostits et al. 2002, Uma Rani \& Vairavasamy 2012). Bulls used in the breeding season or at artificial insemination centers for semen collection have reduced fertility because of DJD (Persson et al., 2007). The present study aims to report the epidemiological, clinical and pathological findings observed in cattle and buffalo diagnosed with DJD in the state of Pará, Brazil in a period of 15 years.

\section{MATERIALS AND METHODS}

The retrospective study included observations made from 1999 to 2014 regarding 35 animals (11 cattle and 24 buffaloes) by reviewing clinical records concerning epidemiological data and clinical and pathological conditions of cattle and buffaloes diagnosed with DJD and treated at the Veterinary Hospital of the Federal University of Pará, Castanhal, Brazil.

All the treated animals suspected of degenerative joint disease (DJD) underwent general and specific clinical examinations of the musculoskeletal system as described in the literature (Dirksen et al. 1993). Seven cattle and eight buffaloes were necropsied. Three of them were necropsied immediately after death resulting from DJD, and 12 animals that had severe clinical signs of the disease were euthanized according to the protocol prescribed by animal welfare standards (CONCEA 2013). All the joints were inspected, and the bones from the affected joints were collected and macerated for a better characterization of the lesions.

The lesions observed at necropsy were classified according to a modified version of the classification previously described (McGavin \& Zachary 2009). They were grouped into four categories according to their severity: chondromalacia, softening of the articular cartilage $(+)$; erosion, abnormal wear of the cartilage and loss of surface layers, resulting in a washed-out appearance $(++)$; fibrillation, deeper erosions with a visible wear of collagen fibers, and the cartilage may appear yellow to brown (+++); and ulceration/eburnation, notable loss of cartilage up to below the mineralized layer and the subchondral bone. After exposure of the subchondral bone, the bone surface may appear polished and very smooth due to wear, and osteophytes are present $(++++)$.

\section{RESULTS}

From 1999 to 2014, 35 animals with clinical signs of degenerative joint disease (DJD) were treated at the Veterinary Hospital of the Federal University of Pará, Castanhal campus. The most affected animals were 11 cattle, three females, and eight males (seven Nelore, two crossbred, one Guzerá and a mini Puganor ox), aged between two and a half years and 17 years, and 24 buffaloes, 22 females and two males (13 Murrah, three Jafarabadi and eight Murrah $\mathrm{x}$ Mediterranean crossbred), aged between one and a half and 18 years.

Four cattle (Bovines 1, 4, 5 and 7) and one buffalo (Buffalo 15) belonged to the Animal Reproduction Center in the town of Castanhal, state of Pará, for over three years. They were kept in pens and every day received chopped grass (Pennisetum purpureum); $0.5 \%$ of the animal's live weight of a ration consisting of corn, soybeans and wheat bran; mineral salt; and water ad libitum. Semen was obtained of these animals twice a week using an artificial vagina after mounting a properly contained dummy mount (cows out of estrus).

Seven cattle and eight buffalo came from properties located in the northeastern region of the state of Pará, where they were raised extensively on Brachiaria brizantha pastures and received mineral supplementation irregularly. In addition, 15 buffaloes belonged to farms located in the Cachoeira do Arari municipality, Marajó Island, Pará state, and were also raised extensively on native pastures of canarana grass (Echinochloa polystachya), rat-tail grass (Hymenachne amplexicaulis) and pomonga grass (Leersia hexandra) and did not receive mineral salt. 
Clinically the hind limb joints were affected bilaterally in cattle, except in animal 9, which had a bilateral lesion in the scapulohumeral joint (Fig.1). In 19 buffaloes, the affected joints were located in the forelimbs; 16 animals had unilateral lesions (Buffalo 16, 17, 18, 20, 21, 22, 23, 25, $26,27,28,29,30,31,32$ and 33), and three had bilateral lesions (Buffalo 19, 24 and 35). Five buffaloes had the affected joints in the hind limbs, and they were unilateral in two animals (Buffalo 12 and 13) and bilateral in three animals (Buffalo 14, 15 and 34).

The common clinical signs observed in both species were chronic lameness ranging from degree 2 to 4 , stiff gait, postural changes (Fig.2 and 3), reluctance to walk, audible crackles during circumduction of the affected limb, prolonged recumbency and difficulty to stand up, and flexing the affected joints. Additionally, weight loss, pressure sores and increased volume in the tuberosities of the joints were observed. Bovines 4,7 and 8 showed abnormal posture characterized by straight legs that were displaced forward when the animal remained standing. The animals in the Animal Breeding Center, according to the responsible veterinarians, had low semen quality and lost their ability to mount for semen collection.

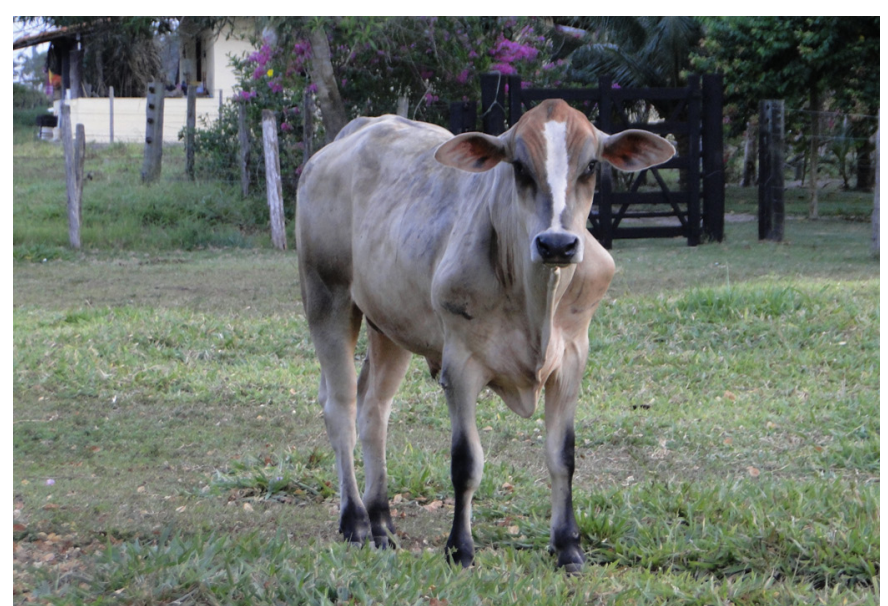

Fig.1. Bovine 9: note the bilaterally increased volume of scapulohumeral joints.

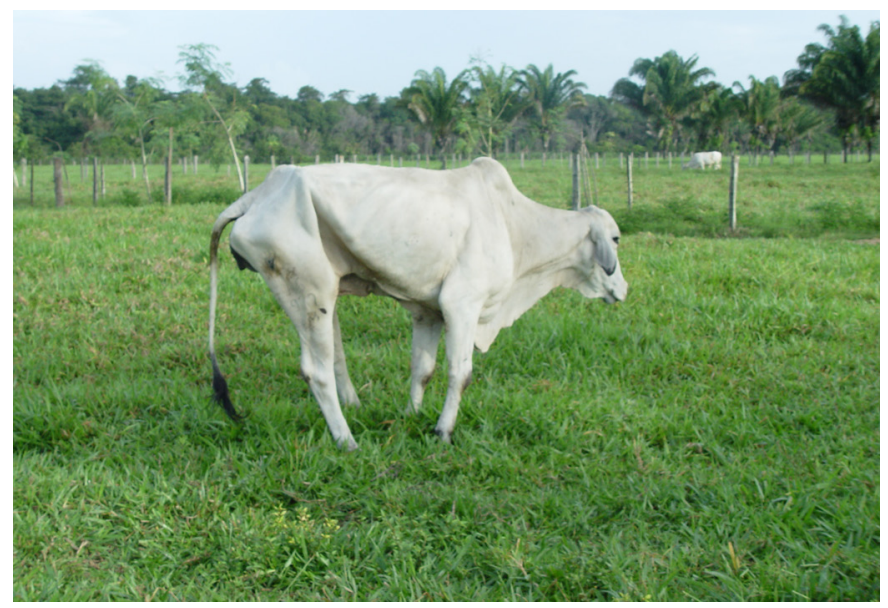

Fig.2. Bovine 2: the animal is standing up with legs straight (decreased hock curvature) and displaced forward; the abdomen is contracted due to joint pain.
All the buffaloes with affected scapulohumeral joints had changes in posture characterized by the forelimb being sometimes displaced forward and sometimes supported on the pastern. Atrophy of the infraspinatus and supraspinatus muscles was also found in these animals, making the spine of the scapula and the scapulohumeral joint more prominent (Fig.3).

The buffaloes affected by DJD raised in native pastures

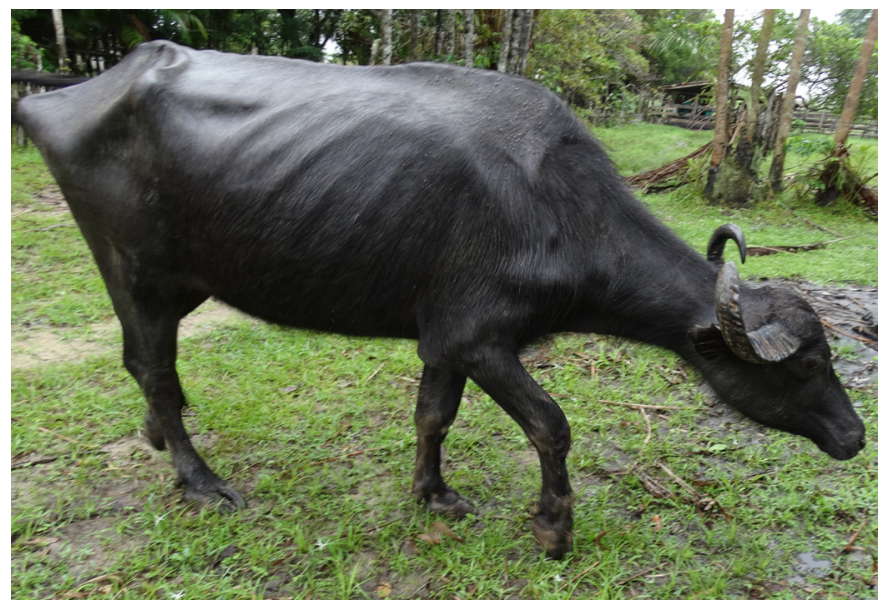

Fig.3. Crossbred 12-years-old buffalo. The animal is standing up with the right forelimb displaced forward; the image indicates atrophy of the supra and infraspinatus muscles and increased volume of the scapulohumeral joint.

in Marajó Island showed clinical signs of severe phosphorus deficiency, evidenced by osteophagia, bone fragility (osteomalacia) and spontaneous fractures.

Data regarding the affected joints and the intensity of the lesions observed in the necropsied animals are shown in Table 1.

The necropsies of all the animals showed unevenness of the articular surface, erosion in the articular cartilage and in the underlying bone tissue and proliferation of periarti-

Table 1. Location and classification of the lesions of the necropsied cattle and buffaloes with degenerative joint disease

Ani-Species Breed Gender Age Affected joints and severity of the lesions mal

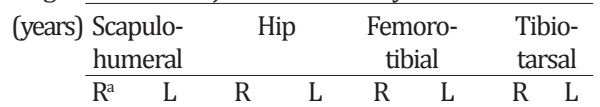

01 Cattle Nelore $\mathrm{M} \quad 14 \quad \begin{array}{lllllllllll}\mathrm{b} & - & +++ & +++ & ++++ & ++++ & +++ & ++\end{array}$

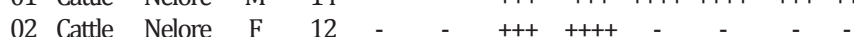

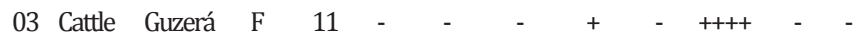

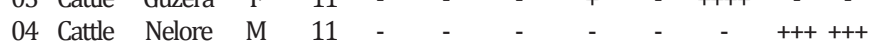

06 Cattle Nelore F $17 \quad-\quad-\quad++\quad++\quad++++++++$ +++ +++

09 Cattle Crossbred M $2.5++++++++$

11 Cattle Puganor M

12 Buffalo Murrah F

13 Buffalo Murrah F

14 Buffalo Jafarabadi $\mathrm{F}$

15 Buffalo Murrah M

16 Buffalo Murrah F

29 Buffalo Murrah F

34 Buffalo Jafarabadi $\mathrm{F}$ 35 Buffalo Crossbred F

${ }^{\mathrm{a}} \mathrm{R}=$ right limbs, $\mathrm{L}=$ left limbs, $\mathrm{b}+$ chondromalacia, ++ erosion, +++ fibrillation, ++++ ulceration/eburnation. 
cular bone tissue with osteophyte formation (Fig.4-6). In animal 2, acetabular bone bubbles were observed in the cranial margin of the obturator foramina (Fig.7). In cattle 1,

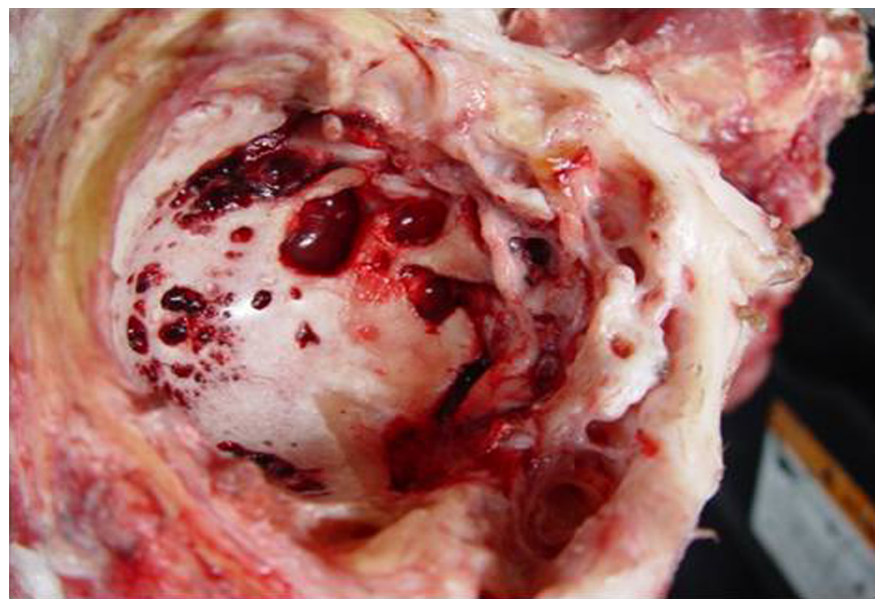

Fig.4. Necropsy findings of a 16-year-old Jafarabadi buffalo. Note the erosion of the left acetabulum articular surface cartilage.

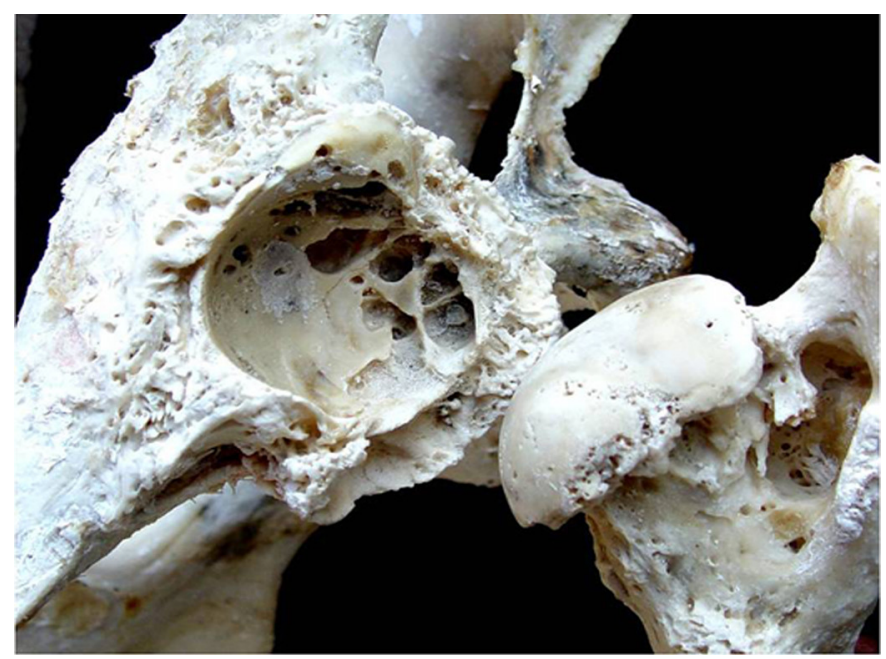

Fig.5. Pelvis and femur of the buffalo from Figure 4 after maceration. There is periarticular bone proliferation and erosion of the left acetabulum and left femur articular surfaces.

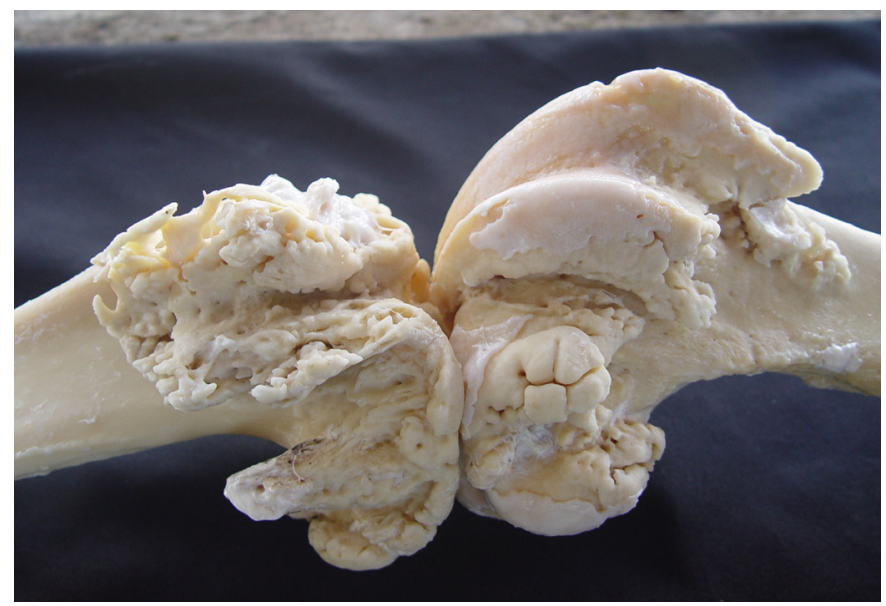

Fig.6. Femur and tibia of the Nelore cow from Figure 2 after maceration. Note the femorotibial joint with marked formation of periarticular osteophytes.

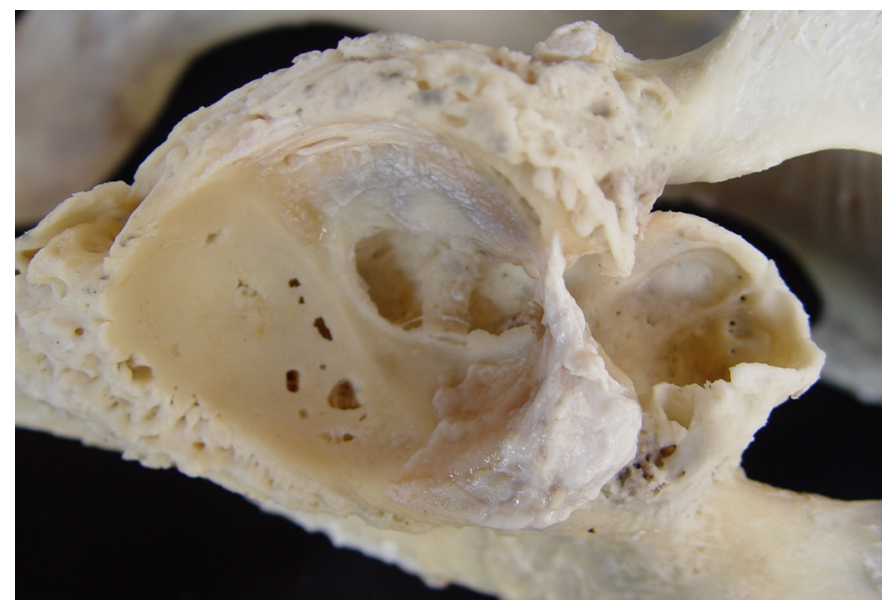

Fig.7. Crossbred bovine, twelve years old. There is erosion of the right acetabulum articular surface with periarticular bone proliferation and formation of a "bone bubble".

2, 4, 6 and 11 and in buffalo 15 and 34, in addition to the hip joint lesions, the round ligament was bilaterally ruptured.

\section{DISCUSSION}

No previous reports were found regarding the occurrence of degenerative joint disease (DJD) in buffaloes. However, it can be stated that this species has similar symptoms to cattle, and this study is the first to report DJD in buffalo as well as in a mini Puganor ox.

In Brazil, DJD was described in dairy cattle in the states of São Paulo and Goiás, where it is one of the causes of culling of cattle from herds (Silva et al. 2004, Silva et al. 2008).

The clinical signs observed in the cattle from the present study, such as lameness, stiff gait, postural changes, reluctance to walk, prolonged recumbency and difficulty to stand- up, corroborate those found in other studies in cattle (Desrochers 2013, Nichols \& Lardé 2014).

Based on clinical examination, the scapulohumeral joint was the most affected joint in buffaloes. The considerable changes in posture when these animals were standing up, with the forelimb displaced forward or placed to lean on the pen, were not observed in cattle.

Nutritional deficiency is one of several etiological factors of DJD, and most likely a major contributing factor to the occurrence of the disease in the buffaloes studied. Although mineral analysis was not performed on the tissues of these animals, previous studies report the occurrence of phosphorus deficiency in the state of Pará, especially in Marajó Island, including in animals from farms where the present study was conducted (Barbosa et al. 2007, Pinheiro et al. 2011). Thus, the articular lesions observed in buffaloes may be a result of phosphorus deficiency.

In three cattle, there was a change in the conformation of the hind limbs, characterized as straight legs. Abnormal conformation of the limbs has a chronic effect on the articular physiology because these joints are not intended to be straight (Desrochers 2013). These cattle are said to have "chicken legs" (Radostits et al. 2002) and are predisposed to joint injuries.

The joint angle is biomechanically important in propul- 
sion or shock absorption while animals walk. Animals with an increased joint angle have a shorter productive life (Desrochers 2013), especially those raised on pasture, which is the reality in the region studied.

Five animals (four cattle and one buffalo) from the Artificial Breeding Center had bilateral lesions in the hip and femorotibial joints in addition to low semen quality and loss of ability to mount for semen collection. DJD should be considered as a contributing cause of infertility in bulls in light of the unsatisfactory semen quality in these animals (Persson et al. 2007).

Bulls from artificial insemination centers are predisposed to DJD due to being constantly subjected to mounts for semen collection, especially when the collection is held in concrete floors (Bargai \& Cohen 1992). These degenerative arthropathies affect mainly the hip and knee joints, reaching an incidence of over $10 \%$ in some breeders (Galloway 1989). In these joints, the degenerative process is a result of the overuse of the joint or of inadequate conformations that cause unintended pressure on the cartilage (Goodrich \& Nixon 2006).

Joint lesions observed in necropsies, characterized mainly by changes in the bone and cartilage tissues of the affected joints, such as surface irregularities, erosions and proliferation of bone tissue, have also been described in cattle in previous studies (Shupe 1961, Carlton \& McGavin 1998, Heinola et al. 2013). These lesions were similar among the cattle and buffaloes, differing only in the frequency of the location of the lesions. The most affected joints were the scapula-humeral joint in buffaloes and the hip joint in cattle. A study conducted with 13 cattle found through postmortem investigations that the hock joints (tarsocrural) were the most affected joint and showed areas of cartilage thinning or complete cartilage loss, eburnation and rupture of the cruciate ligaments (Vaughan 1960). Another study that evaluated 34 infertile bulls found that $88 \%$ of the animals had DJD lesions, the most affected joints were the femorotibial and patellafemoral joints, and in most of the cases, the joints were affected bilaterally (Persson et al. 2007).

In the present retrospective study, the affected animals had a mean age of 9.4 years, indicating that age may have influenced the onset of joint injuries in these animals. However, five animals with DJD were aged between one and a half to three years, showing that young animals are also susceptible to this disease.

In another retrospective study, the occurrence of DJD was reported in the interphalangeal joint and in the sesamoid bone in calves (Mulon et al. 2009). The degree of erosion of the articular cartilage varies with age, inflammation stage and mechanical factors (Shupe 1961). The author also states that DJD occurs in older animals and is most often observed in larger, freely movable joints.

The occurrence of acetabular bone bubbles in the cranial margin of the obturator foramina observed in the present study has also been previously described (Radostits et al. 2002) in animals with DJD. Loss of proteoglycans and improper water binding cause the articular cartilage to become soft, a condition known as chondromalacia. Chondro- malacia is followed by abnormal wear on the cartilage and loss of the very superficial layers, and early erosion occurs, as observed in some of the animals of the present study. As the lesions progress, the erosions become deeper, the collagen fibers are worn macroscopically along their radial arrangement, and fibrillation may be observed (Benett \& Bauer 1931, Weisbrode et al. 1982, McGavin \& Zachary 2009).

\section{CONCLUSIONS}

The present study reports the first occurrence of the degenerative joint disease (DJD) in buffaloes and in a mini ox, showing that these animals are susceptible to DJD.

In buffaloes, the main factor that predisposed them to the emergence of DJD was likely phosphorus deficiency, unlike in cattle, where the anatomical conformation defects of the hind limbs, chronic trauma due to the activity performed and old age were the factors that likely contributed to the emergence of the illness.

In both species, clinical signs were similar. However, in buffaloes, the change in posture characterized by displacement of hind limbs forward was the most noticeable sign.

The most affected limbs were the hind limbs in cattle and the fore limbs in buffaloes.

Acknowledgements.- The authors would like to thank Conselho Nacional de Desenvolvimento Científico e Tecnológico (CNPq), Fundação Amazônia Paraense de Amparo à Pesquisa (FAPESPA), Pró- Reitoria de Pesquisa e Pós Graduação da Universidade Federal do Pará (PROPESP-UFPA), INCT Informação Genético-Sanitária da Pecuária Brasileira and Coordenação de Aperfeiçoamento de Pessoal de Nível Superior (CAPES) for financial support and scholarships. J.D.B. Neto has a research fellowship from CNPq.

\section{REFERENCES}

Baccarin R.Y.A., Machado T.S.L., Lopes-Moraes A.P., Vieira F.A.C. \& Michelacci Y.M. 2012. Urinary glycosaminoglycans in horse osteoarthritis: effects of chondroitin sulfate and glucosamine. Res. in Vet. Sci. 93(Suppl.1): 88-96.

Barbosa J.D., Oliveira C.M.C., Duarte M.D., Albernaz T.T., Oliveira C.A., Riet-Correa G. \& Riet-Correa F. 2007. Phosphorus deficiency in buffalo in the state of Pará, northern Brazil. Italian J. Anim. 6(Suppl.2):971-973.

Bargai U. \& Cohen R. 1992. Tarsal lameness of dairy bulls housed at two artificial insemination centers: 24 cases (1975-1987). J. Am. Vet. Med. Assoc. 201(Suppl.7):1068-169.

Biasi F., Rahal S.C., Volpi R.S. \& Sequeira J.L. 2005. Cranial cruciate ligament reconstruction in dogs associated or not to chondrointin sulfate. Arq. Bras. Med. Vet. Zootec. 57(Suppl.4):442-447.

CONCEA 2013. Diretrizes da Prática de Eutanásia do CONCEA. Lei no. 11.794, out. 2008, Conselho Nacional de Controle de Experimentação Animal. Available at <http://www.ufrgs.br/ceua/normas/diretrizesda-pratica-da-eutanasia-concea-2013> Accessed in January 2014.

Benett G.A. \& Bauer W. 1931. A systematic study of the degeneration of articular cartilage in bovine joints. Am. J. Pathology 7(Suppl.4): 399-413.

Brooks P. 2002. Impact of osteoarthritis on individuals and society: how much disability? Social consequences and health economic implications. Curr. Opinion Rheumatol. 14(Suppl.5):573-577.

Carlton W.W. \& McGavin M.D. 1988. Thompson's Special Veterinary Pathology. $2^{\text {nd }}$ ed. Artmed, Porto Alegre, p.480-482.

Desrochers A. 2013. Non-Infectious Lameness. WCDS Adv. Dairy Technol. 25:255- 266.

Dirksen G., Gründer H.D. \& Stöber M. 1993. Rosemberger: Clinical Examination of Cattle. $3^{\mathfrak{a}}$ ed. Guanabara Koogan, Rio de Janeiro, p.315-338. 
Frisbie D.D., Al-Sobayil F., Billinghurst R.C., Kawcak C.E. \& McIlwraith C.W. 2008. Changes in synovial fluid and serum biomarkers with exercise and early osteoarthritis in horses. Osteoarthritis and Cartilage 16 (Suppl.10):1196-1204.

Galloway D.B. 1989. Factors affecting fertility in bulls. Revta Bras. Reprod. Anim. 1:27-46.

Goodrich L.R. \& Nixon A.J. 2006. Medical treatment of osteoarthritis in the horse-a review. Vet. J. 171(Suppl.1):51-69.

Heinola T., Grauw J.C., Virkki L., Kontinen A., Raulo S.M., Sukura A. \& Konttinen Y.T. 2013. Bovine Chronic Osteoarthritis Causes Minimal Change in Synovial Fluid. J. Comp. Pathol. 148(Suppl.4):335-344.

Lima I.R. 2009. Clinical and radiographic study of the distal ends of limbs of male beef cattle. Master's Dissertation, Escola de Veterinária, Universidade Federal de Goiás, Goiânia. 70p.

McGavin D.M. \& Zachary J.F. 2009. Basis of Veterinary Pathology. 4를 ed. Elsevier, Rio de Janeiro, p.1100-1102.

Mulon P.Y., Babkine M., D’Anjou M.A., Girard C. \& Desrochers A. 2009. Degenerative disease of the distal interphalangeal joint and sesamoid bone in calves: 9 cases (1995-2004). J. Am. Vet. Med. Assoc. 234 (Suppl.6):794-799.

Nichols S. \& Lardé H. 2014. Noninfectious joint disease in cattle. Vet. Clin. North Am., Food Anim. Pract. 30(Suppl.1):205-223.

Persson Y., Söderquist L. \& Ekman S. 2007. Joint disorder; a contributory cause to reproductive failure in beef bulls? Acta Vet. Scand. 49(Suppl. 31):1-7.

Pinheiro C.P., Bomjardim H.A., Andrade S.J.T., Faial K.C.F., Oliveira C.M.C. \& Barbosa J.D. 2011. Levels of phosphorus, copper, cobalt and zinc in water buffalo (Bubalus bubalis) on Marajó Island, Pará. Pesq. Vet. Bras. 31(Supl.3):193-198.

Radostits O.M., Gay C.C., Blood D.C. \& Hinchcliff K.W. 2002. Veterinary Clinic: a treatise on the diseases of cattle, sheep, pigs, goats and horses. 9a ed. Guanabara Koogan, Rio de Janeiro, p.507-511.

Rebhun W.C. 2000. Dairy Cattle Diseases. Roca, São Paulo, p.490-491.

Scott P.R., Rhind S. \& Brownstein D. 2000. Severe osteochondrosis in two 10 month old beef calves. Vet. Rec. 147(Suppl.21):608-609.

Shupe J.L. 1961. Arthritis in cattle. Can. Vet. J. 2(Suppl.10):369-376.

Silva L.A.F., Silva E.B., Silva L.M., Trindade B.R., Silva O.C., Romani A.F., Fioravanti M.C.S., Sousa J.N., Franco L.G. \& Garcia A.M. 2004. Culling causes in adult dairy cows. Revta Bras. Saúde Prod. Anim. 5(Sup.1):9-17.

Silva L.A.F., Coelho K.O., Machado P.F., Silva M.A.M., Moura M.I., Barbosa V.T., Barbosa M.M. \& Goulart D.S. 2008. Culling causes in confined Holland breed cows in a population of 2083 bovines (2000-2003). Ciênc. Anim. Bras. 9(Supl.2):383-389.

Takizawa M., Yatabe T., Okada A., Chijiiwa M., Mochizuki S., Ghosh P. \& Okada Y. 2008. Calcium pentosan polysulfate directly inhibits enzymatic activity of ADAMTS4 (aggrecanase-1) in osteoarthritic chondrocytes. FEBS Letters 582(Suppl.19):2945-2949.

Thomas R. \& Johannsen N. 2011. Articular depressions in domestic cattle phalanges and their archaeological relevance. Int. J. Paleopathol. 1 (Suppl.1):43-54.

Tryon K.A. \& Farrow C.S. 1999. Osteochondrosis in cattle. Vet. Clin. North Am., Food Anim. Pract. 15(Suppl.2):265-274.

Uma Rani R. \& Vairavasamy K. 2012. Clinical management of degenerative joint disease in a cow. India Journals 13(Suppl.2):277-278.

Vaughan L.C. 1960. Osteoarthritis in cattle. Vet. Rec. 72:534-538.

Weaver A.D. 1997. Lameness in Cattle. $3^{\text {rd }}$ ed. W.B. Saunders, Philadelphia, p.162-170.

Weisbrode S.E., Monke D.R., Dodaro S.T. \& Hull B.L. 1982. Osteochondrosis, degenerative joint disease, and vertebral osteophytosis in middle-aged bulls. J. Am. Vet. Med. Assoc. 181(Suppl.7):700-705. 